\title{
Surfaces
}

\section{Rhapsodic Readings: The Ion and Literary Knowledge}

\section{Craig Moyes}

Volume 6, 1996

LES ÉCONOMIES DISCURSIVES DU SAVOIR ET DE LA CULTURE DANS LE SILLAGE DE L'OEUVRE DE BILL READINGS

THE DISCURSIVE ECONOMIES OF KNOWLEDGE AND CULTURE, WITH CONSTANT REFERENCE TO THE WORK OF BILL READINGS

URI : https://id.erudit.org/iderudit/1064861ar

DOI : https://doi.org/10.7202/1064861ar

Aller au sommaire du numéro

Éditeur(s)

Les Presses de l’Université de Montréal

ISSN

1188-2492 (imprimé)

1200-5320 (numérique)

Découvrir la revue

Citer cet article

Moyes, C. (1996). Rhapsodic Readings: The Ion and Literary Knowledge. Surfaces, 6. https://doi.org/10.7202/1064861ar
Résumé de l'article

Dans le contexte des débats contemporains sur le statut institutionnel de la littérature, cet article propose une lecture approfondie de l'Ion de Platon afin de s'interroger sur le problème de la connaissance littéraire. La réponse négative offerte par Socrate sera répétée par deux apologistes de la littérature, C.-A.Sainte-Beuve et T.S. Eliot. 


\title{
Rhapsodic Readings: The Ion and Literary Knowledge
}

Craig Moyes

Université de Montréal / E.N.S. Fontenay-Saint-Cloud moyes@ere.umontreal.ca / moyes@ens-fcl.fr

Surfaces Vol. VI. 216 (v.1.0A - 10/10/1996) - ISSN:

1188-2492

Copyright for texts published in Surfaces remains the property of authors. However, any further publication should be accompanied by an acknowledgement of Surfaces as the place of initial publication.

\begin{abstract}
Within the context of current debates on the institutional status of literature, this paper discusses the problem of literary knowledge through a detailed reading of Plato's Ion. It argues further that the structure of the negative response that Socrates offers to the rhapsode is curiously repeated by two modern apologists for literature, Sainte-Beuve et Eliot.
\end{abstract}

\section{RÉSUMÉ}

Dans le contexte des débats contemporains sur le statut institutionnel de la littérature, cet article propose une lecture approfondie de l'Ion de Platon afin de s'interroger sur le problème de la connaissance littéraire. La réponse négative offerte par Socrate sera répétée par deux apologistes de la littérature, C.-A.Sainte-Beuve et T.S. Eliot. 
It has been over fifteen years since Paul de Man first diagnosed a resistance to theory within literary studies in North America, and questions concerning the precise relation of theory to institutionalized practices of reading literature as yet show no signs of abating. If anything, the debate has grown, but the professional crisis that was so often described in terms of a struggle between two opposing camps - the theorists against the traditionalists, Derrida versus Bate - has since splintered into so many critical, methodological and political positions that grouping them all under a single rubric ("theory" or "conservatism") would in many ways be today a serious misnomer. Not only is "the critical cat so far out of the bag that one can no longer ignore its existence",[ $\underline{\mathbf{1}}$ ] as de Man wryly put it in 1982, the cat has had kittens.

We may be beginning to suspect, however, that much of the caterwauling that has characterized the professional literature of recent years has perhaps less to do with "crisis", "paradigm shift" or "foreign invasion", than with one of the constitutive problems of literary study, namely, is it worthwhile doing at all? Or to phrase this bald question somewhat more precisely: if the university is an institution geared to the production of knowledge (and not a museum, salon, or vocational school), can literary analysis produce knowledge unavailable in other fields of research? This is the real sub-text of much of the shopworn theory/anti-theory debate: the recognition of the shakiness of the epistemological terrain under the feet of literary scholars and the concomitant search for firmer ground. As Peter Brooks writes in a recent issue of Critical Inquiry: "Literary critics suffer from bad conscience. They are infected by a continuing suspicion that they don't really have a valid subject to profess".[ $\underline{\mathbf{2}}$ ]

Now, this anagnorosis was perhaps inevitable, given that literature departments were born rather late in the academic day from now largely discredited nineteenthcentury positivisms and nationalisms.[ $\underline{\mathbf{3}}$ ] The fact remains, however, that questions regarding the cognitive value of literary study within systems of state-authorized knowledge reproduction are much older than the current debates on the status of literature or literary theory within the university. De Man famously pointed out the links to the medieval curriculum, but, as I shall argue, the essential terms of the debate go as far back as fourth-century Greece, to Plato's Ion, where the relatively new figure of the philosopher asks the 
guardian and performer of literature point-blank what it is that he actually knows. In a gesture which has since been many times repeated both within literary criticism and without, Socrates misreads Ion's answer, "he will know what a man and a woman ought to say", as being at once ridiculous and excessive, for he understands it to mean, "he will know what men and women know". This misreading is then mobilized to exclude literature from knowledge, which is to say, from scientific knowledge altogether.

The firm belief that literary critics do not at the present time have a valid subject within the concert of academic disciplines underwrites, to take but one particularly outspoken example, Paisley Livingston's Literary Knowledge. At once a salubrious attack on the misuse of science as a straw man in literary criticism, and a bold attempt to clear away some of the excessive verbiage and loose relativism in a field that still purports to be guided by rational enquiry, Livingston's argument nevertheless wins only a Pyrrhic victory.[ $\underline{4}$ ] What he gains in methodological cogency, he loses in actual knowledge - that is, knowledge of the object he sets out to study in the first place: literature. This follows from his two basic presuppositions which, as we shall see, are anything but new: first, since scientific research is a "unity", [ $\underline{\mathbf{5}}]$ and the only proven method of acquiring knowledge, the study of literature ought therefore be subject to its methods and the findings of literary criticism should be evaluated according to the terms and criteria laid down as valid by science; and second, the "key issue [in literary criticism] is the question of the validity of interpretation",[ $\underline{\mathbf{6}}$ ] or what Livingston terms in several places, "the message in the bottle". If by the first presupposition literature is once again pushed to the far side of the divide separating the "Two Cultures", by the second it can still hop over the fence. In other words, all is not lost: the "message" can still be recuperated as an aid in "the crucial process of hypothesis formation", in order "to refine and complexify the models underwriting research programs within the human sciences".[ 7 ] Literature then, in Livingston's view, ought to be reduced to a kind of crucible for thought experiments on a grand scale, a fictive place where psychological, sociological or economic theories may be extracted by the critic, and later applied to the "real world" according to the scientific norms which regulate those disciplines.

Needless to say, one must be very selective in one's choice of literature if one reads it only to find hypotheses that will prove useful to current research in the social 
sciences. But even given such a selection, is literature then to be no more than a lumber-room of accumulated fictions, where "hypotheses" may be occasionally pulled out of the pile by the critic and later redeemed as "knowledge" upon presentation to his scientific colleagues? In other words, is the rhapsode's role only to work as the philosopher's assistant, furnishing the bits of Homer that will fit those theories under construction?

We may also ask: is Ion really too intellectually impoverished to have a theory of his own? For Plato, of course, the answer is yes. Ion is a rhapsode, and so tailor-made to be the perfect Platonic anti-hero. Reciter of poems, though neither poet nor yet properly actor; "critic" of sorts, though certainly not philosopher - the rhapsode was a sort of itinerent poetic "busker", moving from city to city, presenting his art before audiences at festivals and markets.[ $\underline{\mathbf{8}}$ ] Unlike the bard (aiodos) of Homeric times, the rhapsode did not recite poems of his own composition: he brought together excerpts of already existing poetic text - more often than not Homer - intersplicing his recitation with commentary. As Socrates concedes, he had a dual function: being "obliged to be continually in the company of many good poets, and especially of Homer, who is the best and most divine of them, and to understand his mind, and not merely learn his words by heart" (530c).[ $\underline{\mathbf{9}}$ ] He was, in short, a professional interpreter : that is, he was responsible for both the transmission and the translation of something which needed interpretation, because that something - the Homeric text - did not give itself up to unmediated consumption. The poetic text had to be remembered (rhapsode comes from rhaptein, meaning "to stitch together"), but it had to be read as well. And in that - you will forgive my sudden leap back to the present - the rhapsode could be said to engage in an activity similar to what we now call professing, and what we used to call reading literature.

It is in this dual sense that Ion could be said to read Homer, that is, not simply reciting his poetry, but understanding the critical mediation of the text as something which is, somewhere along the line, problematic. Now still very pertinent in this context is of course de Man's subtle analysis of theory as reading, or more precisely, as the refusal to take reading as a given, as merely the unavoidable mediation between text and understanding. Hence too his fundamental notion of "resistance to theory", which should, of course, be understood at a much deeper level than as a simple institutional opposition to new methodologies. For de Man, resistance is structured within reading itself. 
Where what I shall call the "Socratic" critic might attempt in some way to overcome this resistance by privileging an intention, a code, a grammar, a reference or by ignoring it altogether - de Man's theoretical stance was that much more rigorous (and "rhapsodic") in its consistent refusal to fall back on an extra-literary foundation. To take the notion of resistance in an electrical sense, both history and aesthetics, disciplines which have traditionally shored up the analysis of literature, tend, as it were, to ground.[ 10 ] But if theory is, as in one of de Man's broader definitions, merely the use of language about language,[ $\underline{\mathbf{1 1}}$ ] the internal resistance of the circuit between the reader and the "real" is no longer an impediment, but the invariable occurrence of all such textual mediation, and the resulting release of energy is the force that drives theory. This electrical metaphor will become important when we look more closely at the Ion.

Metaphors aside, however, we know that a "theory", in de Man's sense, is by no means the automatic result of reading. More often than not critical response takes the form of a flight from reading and a corresponding search for solid ground. I wish to argue first, that this flight is not simply the product of recent Anglo-American institutional history, but is part and parcel of the problematic nature of literary mediation and the possiblility of literary knowledge - an aporia pointed up clearly by the Ion; and second, that the Socratic position remains the unacknowledged epistemological cornerstone of not only the flinty scientific rationalism of Livingston, but also of the positions of two very "literary" critics, Charles Augustin Sainte-Beuve and T.S. Eliot, working out of different national traditions.

In an article of 1990, entitled "Why is Theory Foreign?", Bill Readings asks a similar question to my own (which might be phrased, "Why won't Socrates listen?"). In his answer, eloquent and to the point, he characterizes the twin (and competing) practices of literary theory and literary criticism in terms of borders, both national and epistemological. He claims that English criticism has, since the New Critics, been concerned with justifying the self-sufficiency of literature. Understanding, according to this view, procedes from inside the text; it just happens, once, that is, the text has been properly framed by the critic. Literary theory, on the other hand, is seen as an essentially foreign activity, breaking in upon that frame from outside, from other domains (e.g. philosophy) or other countries (e.g. France) onto the native territory of English letters. In a brilliant reading of Dryden, he 
deconstructs that opposition by arguing that theory ought not to be seen in terms of inside or outside, domestic or foreign, traditional or fashionable; rather, he considers that it has always been a part of English criticism, unstated as "reading" which, in Dryden at any rate, is conscious of itself not as a process either intrinsic or extrinsic to the text, but as an immediate "twinkling". "The twinkle or blink," writes Readings, "marks a hiatus, an unaccountable moment that founds the possibility of a switch between two modes of perception. To read this moment is to deny the stability of the foreign outside or the native inside. The twinkle is itself neither read nor seen, yet it opens the frame to reading of its exteriority and demands a theorization of the interiority of reading. [...] Reading takes place on the edge [...]".[ 12 ]

Bill was one of the finest readers I have known, not only because of his being already extremely "well-read", but also because he consistently refused to fix his reading on the stable ground of method or critical dogma. With an astonishing quickness that cut across boundaries, his was without a doubt a brilliance that "twinkled". An Englishman, trained in Oxford and Geneva, leaving his position in the United States to teach in Quebec (where the question of a new border was being hotly debated), Bill was keenly aware of the instutional and political ramifications of what has come to be termed, in anglophone North America in any case, "theory". He writes: "Theory is valuable in that it is foreign to itself, insofar as it does not constitute a nationality, insofar as it is self-transgressive. Good theory, that is, is reading in the sense that I've tried to describe it: the activity that crosses and transgresses the division of inside from outside that hierarchizes text and interpretation and grounds the possiblility of a closure of reading".[ 13 ] Only in tennis would Bill insist on the absolute fixity of the line - there, no argument, in was in and out was out. I am not sure whether it was a terrible irony, or terribly appropriate, that he was killed while crossing a border and defying gravity at the same time. C'est à la mémoire de sa traversée et de son défi que je dédie cet article.

\section{II}

I have chosen to discuss the Ion at some length because it seems to me to be an altogether fundamental example of the struggle between epistemic and rhetorical 
mediation that is perpetually taking place within literary criticism. Beneath the mocking banter of a dialogue with no other apparent reason than to show Socrates making short work of a guileless rhapsode lies a deadly serious confrontation between poetico-rhetorical and dialectical theories of language. This conflict is spatialized in the following way. Socrates's argument attempts to establish a firm ontological basis for language, either from below, by anchoring speech to specific classes of men, or from above, by having it subtend from a divinity. It is the protean speech of the rhapsode, however, with its reference slipping between the antique world of Homer and the present audience of Athens, that is constantly threatening to escape this vertical dependency and spread out horizontally upon the space of the polis, where it must be contained or excluded by other (notably legal) means.

Everyone is familiar with the expulsion of poets from the Republic. The commonplace reason given is that, following the allegory of the cave, poetic imitation is "two removes" from the reality of the sovereign Good. What is less often noted, however, is that it is only poetry that is singled out for ostracism over and above the other mimetic arts. In the Republic, as in the Ion, poetry is specifically rejected because it is a linguistic act that diverts language from its true vocation, which is justice. Justice, as an Idea, can only be arrived at through dialectic. And since the object of the city is justice, its foundation can only be dialogic; language, therefore, holds a privileged position. The Ion maintains these same presuppositions, yet has the added twist of staging a city which, far from being a utopia, is the actual city of Athens, a city in which Socrates, moreover, holds a position of some authority. The roles of philosopher and rhapsode are thus set up not as mere abstractions, but as an incarnated political drama.

Let us first briefly go over the argument of the dialogue. Socrates begins, as usual, by giving his interlocutor rope enough. He allows that the rhapsode must be both performer and critic: "I am sure that no man can become a good rhapsode who does not understand the meaning of the poet. For the rhapsode ought to interpret [hermenea] the mind of the poet to his hearers, but how can he interpret him well unless he knows what he means (530c)?" Ion agrees with Socrates, stating further that this critical function is the most difficult part of his art. Despite its difficulty, Ion is convinced that no one speaks better of Homer than he. We have no choice but to take him on his word, however, since whatever criticism Ion can muster remains at the level of 
performance, a performance which moreover Socrates simply refuses to hear. There is good reason for this. Socrates has absolutely no need to listen to the rhapsode given the $a$ priori that underwrites his philosophy: that language, whether philosophical or poetic, is always of something. Thus, bypassing the poetry itself, he asks why Ion should be able to speak only of Homer, when other poets write about the same subjects. This slide towards deixis permits Socrates's first (and fundamental) explicit argumentative step. He establishes, with the nodding consent of Ion, that in order to judge any discourse, one must know the rules of the art [technè] to which that discourse applies. Who judges best a discourse on number? Why, the mathematician. Who best recognizes the value of a speech on war? The general. The problem, for Socrates, is that here is a rhapsode who claims to be able to recognize the value of all these arts and more solely because they are in Homer.

Moreover, Ion is interested only in Homer; other poets treating the same subjects put him to sleep. Socrates's first conclusion is negative: "The reason, my friend, is not hard to guess. No one can fail to see that you speak of Homer without any art or knowledge. If you were able to speak of him by rules of art, you would have been able to speak of all other poets; for poetry is a whole (532c)."

The ironic weight of the last phrase, "for poetry is a whole", will become clearer as we proceed. It is sufficient for the present to note that, as in the Republic, poetry is singled out for an especially biting attack. The stakes are clear from the moment Ion, ironically or not, calls Socrates "wise". Socrates's irony, in return, is unmistakable: "O that we were wise, Ion, and that you could truly call us so; but you rhapsodes and actors, and the poets whose verses you sing, are wise; whereas I am a common man, who only speaks the truth. For consider what a very commonplace and trivial thing is this which I have said - a thing which any man might say: that when a man has acquired a knowledge of a whole art, the inquiry into good and bad is one and the same" (532d-e). All the other mimetic arts, as "whole arts", are considered technein; only poetry is excluded from this classification. Whereas the excellence or faults of other arts may be deduced from the rules and signs proper to that art, Ion is unable to reach any conclusion from his own, and, in the face of Socrates's arguments, can do nothing but obstinately insist that he does "speak better and have more to say about Homer than any other man" (533c).

Everything turns upon Socrates's ironic introduction: "how can he interpret him [the poet] well unless he 
knows what he means?" Indeed, the further we progress in the reading of the dialogue, the more ironic it becomes, since it becomes increasingly clear that Ion cannot in fact "know" anything, at least not in the sense that Socrates understands "knowledge". Since, for Socrates, there is a narrow identification between a man, his art, and his language, it is always possible to deduce one term from another. Technical[ 14 ] knowledge implies the ability to judge technical language wherever it occurs, and vice versa. Ion, though he speaks "artfully", can deduce nothing; therefore, concludes Socrates, he has no knowledge and no art.

Having no art, Ion should in theory have nothing to say. And, while yielding in theory, the inexhaustible Ion yet protests: "I cannot deny what you say, Socrates. Nevertheless I am conscious in my own self, and the world agrees with me, that I do speak better [...]," etc. Socrates's response and next argumentative step: his discourse can in no way be the result of an art (which implies the use of reason), but is due to a kind of divine transport. No man, while he retains his reason, "has the oracular gift of poetry" (534b). All Ion's discourse, then, flows directly from Homer, and from the divinity that inspired him, through a sort of magnetic chain. Now this conclusion (which Jowett claims "delights" Ion)[ 1 ] reduces the rhapsode ontologically to zero, or at best to the status of a part-time medium, now inspired, now asleep.

Ion may seem convinced by Socrates, but we ought to remain sceptical. Socrates asks Ion if the performer or the spectator can be said to remain in control of his reason if he feels fear in the absence of any real threat. Ion responds with an emphatic "No indeed", which Socrates takes as further proof of the chain of divine unreason. Whereupon Ion adds quite innocently, speaking of his spectators: "[...] for I look down upon them from the stage, and behold the various emotions of pity, wonder, sternness, stamped upon their countenances when I am speaking: and I am obliged to give my very best attention to them; for if I make them cry I myself shall laugh, and if I make them laugh I myself shall cry, when the time of payment arrives" (535e). This aside merits no response from Socrates, who continues in his description of the effects of a divine inspiration that seemingly flows irresistibly from one end of the chain to the other. Still, the sudden irruption of rational calculation in the middle of this chain should be enough to disrupt the purity of the Socratic image. 
In fact, Ion himself remains only half convinced, and notably not by Socrates's logic, but by his "eloquence": "That is good, Socrates; and yet I doubt whether you will ever have eloquence enough to persuade me that I praise Homer only when I am mad and possessed; and if you could hear me speak of him I am sure you would never think this to be the case" (536d). "I should like very much to hear you," rejoins Socrates, but he never once lets Ion speak of poetry, and instead returns the dialogue to his initial proposition, the adequation of techne and language. Here, he pushes the argument further to affirm the absolute independence of the arts. Still, his argumentation remains more or less the same: if each art is distinct, each having specific knowledge and language proper to it and it alone, how can the rhapsode pretend to speak of everything? Socrates once again enumerates various arts of which Ion must admit to being ignorant. Finally, tired perhaps of negative responses, Socrates asks him what the rhapsode does know. Here is Ion's answer: "He will know what a man and a woman ought to say, and what a freeman and what a slave ought to say, and what a ruler and what a subject" (540b). In other words, all language which does not depend on technical knowledge. A very good answer indeed, since Ion manages to escape, however naïvely, however briefly, being trapped by the restrictive definition which founds Socrates's argument. But Socrates is nothing if not persistent, and he forces Ion to exclude one by one all the possible arts from his supposed field of mastery. Notice, however, that Socrates never directly responds to Ion's demand that he prove the divinity (or madness) of his rhapsodizing: save for Socrates's own brief excursion into flowery description, his is always an argument by exclusion. And his conclusion is no less exclusive: either the rhapsode is a kind of Proteus, and therefore dishonest; or he is divine, and therefore in dispossession of his reason. Criminal or madman is the single sorry choice left for Ion.

Socrates succeeds, of course, by displacing the argumentation away from the nature of poetry as a discourse whose reference is essentially problematic, and replacing it upon the ground of an ontologically anchored theory of language. I have referred to Ion as a "critic", but notice that we are never allowed an example of his art. He is not only continually cut off by Socrates, but even if he were given his say, the argument repeatedly demonstrates the epistemological impossibility of his speaking, that is, of his speaking a rational language as Socrates would have us understand it. As we have seen, Socrates assumes a tripartite 
ontology such that there is adequation between a man and the art he practices, between an art and its language, and finally between man as technician and language as technical. Any serious analysis of literary utterance is, needless to say, impossible in such a system, and Ion has good reason to desist. (A similar result might be had by asking a Proust specialist for his theory of butter and flour in the baking of madeleines.) Poetic language can only be understood outside this triangle. For Socrates, however, the only other possibility that would not endanger the ontological stability of the structure he has set up is to give poetic language itself a different ontological status, to call it divine, thus stabilizing and excluding it at one and the same time.

What Socrates wants to avoid at any price, what he sees as fundamentally dangerous, is to admit the possibility of a language without ontological foundation. Yet this is precisely what is hinted at by each inept and giddy response by the rhapsode. For de Man, it is that gesture, that "resistance", which calls into being the possibility of theory. He writes: "Whenever this autonomous potential of language can be revealed by analysis, we are dealing with literariness and, in fact, with literature as the place where this negative knowledge about the reliability of linguistic utterance is made available". [ 16 ] This, of course, is the analysis that Socrates refuses categorically, since it would throw into question the sole means of accession to rational knowledge which, in the Platonic system, is always through dialectic. The queer and seemingly repetitive structure of the dialogue is, I believe, a result of this presupposition. It is entirely significant that Socrates's words touch Ion's "soul" [psukhe] and not his mind [nous] (535a), precisely at the point where Socrates repeats five times that a poet's soul is the dispossession of his reason [nous]. This may only be a supplemental irony; nevertheless, after the first stage of the argument it is no longer Socrates's argumentation that convinces Ion, but his "eloquence". Ion simply will not learn through dialectic; Socrates is therefore forced to change tactics and switch to rhetoric. Naturally, Socrates's aims change with his strategy, since rhetoric can never bring knowledge [epsiteme] within the Platonic system, but can at best hope to teach a true opinion [doxa alethès]. But Ion remains, as we have seen, only half convinced. Socrates tries his argument once more but, faced with the obstinate resistance of Ion, is ultimately forced to invoke his legal authority, issue a final ultimatum, and immediately terminate the dialogue. 
This text contains a final twist which we ought not to neglect. We are reminded right at the end that Socrates has a real political role to play just as the dialogue winds up with the curious exchange on the military art of the general. Socrates admits willingly, indeed insists, that Athens could accept a foreign general - Ion would not be disqualified for that reason - but he must genuinely be a general, that is, a general and nothing else. The rhetorical flux of becoming must never be allowed to take the place of the dialectical understanding of being. Allowing the mercurial ontology of Ion to take up residence in a city founded upon the solid rock of identity would be, in political terms, tantamount to yielding up the polis to anarchy.

It is, moreover, entirely consistent with this dialectical foundation of knowledge that Socrates should eventually leave the city of Athens for his Republic. "I want to know whether ideals are ever fully realized in language", Socrates asks Glaucon in the later work. "Does not the word express more than the fact, and must not the actual, whatever a man may think, always in the nature of things, fall short of the truth?" (473a).[ 17 ] It is obvious that what is at stake for Plato is the status of language, not, as is often supposed, the question of mimesis, and that these stakes are very high indeed. Moreover, the dialectician is in direct competition with the poet for its privileged use. Since both pretend to somehow exceed the limits of a single technè, the poet will be seen as consistently undermining the claims of the philosopher to be the rightful legislator of language. Ion is therefore drawn - and with good (Platonic) reason as one of the silliest characters in the Socratic Dialogues.[ 1 8 $]$

But for all his fecklessness, Ion nevertheless manages to indicate the seriousness of the philosophic stakes. His only real response to Socrates, "He will know what a man and a woman ought to say" (540b), is thus much more than an unwitting feint; indeed, it is the very crux of the dispute. For notice that Ion's words echo, albeit obliquely, Socrates's own introduction: "consider what [...] I have said, a thing which any man might say [...] " (532e).[ 19 ] For both characters, what is at stake is the right to speak generally, that is, to escape the dependency of technical reference. Two possibilities of such a metadiscourse are suggested by the Ion: the vertical idealism of Socrates which surmounts the technical real dialectically; or the horizontal rhapsodizing of Ion, which doubles the real mimetically. 
Where both co-exist, it is only at the cost of a profound epistemological unease.

\section{III}

In "The Resistance to Theory", de Man describes what I take to be precisely the same conflict (though now, of course, highly institutionalized) by referring to the malaise contained within the medieval curriculum: "Rhetoric, by its actively negative relationship to grammar and logic, certainly undoes the claims of the trivium (and by extension, of language) to be an epistemologically stable construct".[ 2 20 ] I should like to argue that this selfsame tension is endemic in all theories which attempt to gain a toehold on the shifting sands of literary reference. The problem can be seen as one both of political borders and linguistic mediation. In the Ion, Socrates's debt to the polis mediates his relationship to language in the way we have seen; the stateless rhapsode, on the other hand, militates (badly, it is true) for the recognition of an unmediated - or at least differently mediated - speech, whose reference is not only not that of the "technical real" of Socrates, but is moreover that of a text which has no fixed place in that real, being unwritten, and so quite literally displaced with each performance. And although Socrates is loath to admit it, whatever its ontological status, Homer is a text which produces real effects both on the rhapsode and on his audience. His only means of explaining it is, quite literally, to explain it away, but interestingly enough precisely as an entirely unmediated experience: the cognitive value of the rhapsode's performance is zero for the very reason that the internal resistance of the circuit between the divinity and the audience is equal to zero. What Socrates steadfastly refuses to come to terms with is that the resistance of the rhapsode cannot be explained away through a reference to inspiration. Though we are never permitted to judge, the existence of the critical act itself is what poses the central problem for Socrates: how can rational discourse (which, as we have seen, is deictic and dialogic) refer to an object with no other basis than language? The reason behind its reference is even more dubious that that of poetry itself. Perhaps that is why critical discourse has always found it easier to explain by first Socratically silencing its object, by pointing to something else seemingly more solid than literary utterance: God, Genius, History, Ideology, etc. 
Two modern critics - in their time, the most important of their respective countries - demonstrate, in exemplary fashion, this same tendancy to turn away from the unique character of literary mediation. Though both Eliot and Sainte-Beuve would have claimed to be working in the service of art - never would they have thought of banishing poets - each makes the necessary Socratic gesture, having first to stake out for himself the philosophic privilege of metadiscourse. But whatever the measure of idealism thereby gained, it comes, as Ion knew, at rhetorical cost. What is striking in the case of Eliot is that he criticizes his predecessor on that very point without himself being cognizant of the dangers for his own practice. In "The Perfect Critic" (1920), for example, Eliot writes: "Sainte-Beuve was a physiologist by training; but it is probable that his mind, like that of the ordinary scientific specialist, was limited in its interest, and that this was not, primarily, an interest in art. If he was a critic, there is no doubt that he was a very good one; but we may conclude that he earned some other name".[ $\underline{\mathbf{2 1}}$ ]

To say that Sainte-Beuve, who spent his life writing and teaching literary history, was not interested in art is, needless to say, a cruel shot by Eliot. But he has a point. From Saint-Beuve's own poetic beginnings in the Cénacle, through his major works on Chateaubriand and Port Royal, his professorship at Liège, and especially his Causeries, literature itself is something that effectively disappears under the weight of his famous method. Consider this succinct description of 1855: "La vraie critique, telle que je me la définis, consiste plus que jamais à étudier chaque être, c'est-à-dire chaque auteur, chaque talent, selon les conditions de sa nature, à en faire une vive et fidèle description, à charge toutefois de le classer ensuite et de le mettre à sa place dans l'ordre de l'Art".[ [22 ] His "method" consisted in always looking beyond the work to find the individual genius that constituted it. "A tree is known by its fruit", as we might say tritely, and Sainte-Beuve always discarded the fruit to examine the trunk and roots. A pseudo-scientific classification necessarily followed, and a "physiology" was constructed in order to discover the precise conditions of its growth.

There is no need to multiply the examples. Mutatis mutandis, Sainte-Beuve's method has a peculiarly Socratic presupposition, the same desire to root language firmly to an ontological ground. And it is noteworthy that he shares a similar fear, or at least a profound mistrust, of its rhetorical possibilities: 
"Comment s'y prendre," he writes, "si l'on veut ne rien omettre d'important et d'essentiel à son sujet, si l'on veut sortir des jugements de l'ancienne rhétorique, être le moins dupe possible des phrases, des mots, des beaux sentiments convenus, et atteindre au vrai comme dans une étude naturelle?"[ $\mathbf{2 3}$ ] If it is true that Sainte-Beuve is today more often than not disregarded as a serious critic, his method nonetheless continued to be practised, if only unconsciously, long into our own century.[ $\underline{\mathbf{2 4}}$ ]

In England and America, New Criticism supposedly ushered in a new and more appropriate methodology for the analysis of literary texts. Yet its most illustrious representative, T.S. Eliot,[ 25 ] remained despite himself the other side of the Platonic coin upon which figured Sainte-Beuve. Whereas Sainte-Beuve makes the first Socratic move of indissolubly linking author and language, Eliot makes the second, by attaching language to a sort of divinity.

It is unnecessary to add that Eliot and Sainte-Beuve had very different individual "methods". Sainte-Beuve saw criticism as a conversation (causerie) between a type of necro-physio-psychologist and a departed genius. He asks scattered, occasionally indiscreet questions to which no response " $n$ 'est indifférente pour juger l'auteur d'un livre et le livre lui-même, si le livre n'est pas un traité de géométrie pure, si c'est surtout un ouvrage littéraire, c'est-à-dire où il entre de tout."[ $\mathbf{2 6}$ ] In other words, in literary criticism "everything matters". For Eliot, on the other hand, nothing matters, save for those impressions immediately provoked by the work, which must in turn be jealously guarded from any impurity. "The end of the enjoyment of poetry is a pure contemplation from which all the accidents of personal emotion are removed" (57).

I shall confine my comments to "The Perfect Critic", an article from Eliot's middle period ("Tradition and the Individual Talent", etc.), which sets itself the task of identifying and purging common critical errors. One may sin as a critic, according to Eliot, in two principal ways, either by being too "aesthetic", or by being too "philosophic", each of which errs in the management of emotion. The aesthetic critic, first of all, reacts with a surplus of irrelevant emotion which, because he is really an artist manqué, makes "something new out of the impression" (52). The "technical" or "philosophical" critic, on the other hand, attempts to constrain poetry within too narrow a purview, always tending "to legislate rather than to inquire" (56). Sainte-Beuve falls into this category, being in this "technical" sense too Socratic for 
Eliot, here assuming - unplatonically - that poetry can be a technè. Significantly, however, the position Eliot stakes out for himself is similar to that of Socrates: for both these critics, the technical and the aesthetic, lack a certain type of "general" intelligence, since they do not know how to isolate, and thence to understand, the emotions immediately provoked by the object of their analysis - emotions which "are, when valid, perhaps not to be called emotions at all" (56). They are, on the contrary, impressions, at least when received by a perfect sensibility and systematized by a perfect intelligence: or in other words - Eliot's words - "amor intellectualis Dei" (57).[ 27 ] The perfection of criticism is thus the possibility of an adequate language for the "impressions" of an object whose ontological status is never in doubt. Even an Italian peasant, providing he knows how to read, is capable of being transported by verses of the Divine Comedy. What keeps this raw aesthete from "criticism", however, is his incapacity to isolate the emotions proper to his object from others less pure. The perfect critic, on the other hand, is able finally to fulfil the Arnoldian (and indeed the Platonic) injunction to "see the object as it really is" (57).

But if Eliot refuses Sainte-Beuve the title "critic", his concise remark on the limits and duties of his task goes a long way to describing them both: "He [the critic] must simply elucidate: the reader will form the correct judgment for himself" (55). The implication being that classification follows naturally upon the clarification of a fixed object - which is assumed by both authors. For the one, as for the other, it is impossible to give a valid interpretation of a literary object other than by the $a$ priori presupposition of its ontological fixity: for SainteBeuve, thanks to a method which freezes a single subject behind the work of genius; for Eliot, thanks to a purification of critical intelligence which, by ridding experience of all extraneous emotion, is able to receive "valid" impressions of the object.

Should it then surprise us that, in the political and social writings of these two authors, both call for cultural "standards" whilst inveighing against rhetorical excesses in language?[ 28 ] Two years following the upheavals of the 1848 Revolution, Sainte-Beuve wrote an article entitled "Qu'est-ce qu'un classique". Almost a century later, at the close of the Second World War, Eliot would cite this article in a meditation of his own bearing the same title.[ 29 ] Though both recognized, in their own way, the paradox of the temporal presence of the classic which is perforce absent, [ $\underline{\mathbf{3 0}}$ ] they remained satisfied with evoking a nostalgia for its monumentality. Sainte- 
Beuve's conclusion is entirely characteristic: "[...] il faut choisir, et la première condition du goût, après avoir tout compris, est de ne pas voyager sans cesse, mais de s'asseoir une fois et de se fixer. Rien ne blase et n'éteint plus le goût que les voyages sans fin; l'esprit poétique n'est pas le Juif Errant". [ $\underline{\mathbf{3 1}}$ ]

Now monuments, as we know, ought to remain well bolted to their pedestals. We have seen what happens when, as in the Ion, one of these monuments moves about. For Socrates, there is a link between the political peregrenation of the rhapsode and philosophical slippage of linguistic reference. If they wish to remain part of the city, both Ion and Homer must be stabilised and/or excluded. So when Sainte-Beuve links "complete understanding" with immobility, we should pay attention. Such an understanding proceeds quite clearly from a Socratic refusal of change, and from the studied defense of the polis, protected by a general (or prefect) who would be niether an Ion nor an Ahasuerus. Indeed, when Sainte-Beuve states, during his inaugural lecture at the Ecole Normale in 1858 - "Il y a une tradition: qui le nierait? Elle existe pour nous toute tracée, elle est visible comme une de ces avenues et ces voies immenses, grandioses qui traversaient autrefois l'empire, et qui aboutissaient à la Ville par excellence" who can fail to be reminded of similar grand avenues being installed contemporaneously by Haussmann as riot prevention? For in this Sainte-Beuve was right: in the literary work "il entre de tout". But what neither saw was that this tout is always already in language, where an ontological sifting is fundamentally problematic. One can, of course, choose to work in language as if it were ontologically founded, but only by dint of systematically refusing its rhetorical uncertainty in favour of other more logical (Eliot) or more grammatical (Sainte-Beuve) models. And because of this, the solidity that was so carefully constructed will tend ultimately to unstick. Sometimes, as in the Ion, extra-linguistic constraints will have to be invoked.

Proust, who knew something about reading, saw in Sainte-Beuve's method, "un beau mythe platonicien"[ 32 ] : "Lui, lit pour lire, pour retenir ce qu'il a lu. Pour lui, le livre n'est pas l'ange qui s'envole aussitôt qu'il a ouvert les portes du jardin céleste, mais une idole immobile, qu'il adore pour elle-même, qui, au lieu de recevoir une dignité vraie des pensées qu'elle éveille, communique une dignité factice a tout ce qui l'entoure". [ $\underline{33}$ ] If one only reads to gain access to truths set down in black and white, it is therefore only a matter, for Sainte-Beuve as mutatis mutandis for Livingston, of 
reading the right stuff. But here, once again, searching behind the text for a solidity that can be fenced off and contemplated or taken away and used is to mistake the nature of the literary work; reading is not like a conversation with a great mind or a visit to the tool-shed; it is at once much more and much less than a simple transaction of meaning. Unlike the contemplation of the monument, literary understanding - even of a classic such as Homer - does not proceed from a studied and fixed perspective, but from a unique act of reading, which implies movement through the text even as the text moves through the reader. This movement, opening out onto what Proust called "the soul" or "the celestial garden", but which we may also term "imagination" or even, if we wanted to elaborate a theory, "fictional reference" - this movement, unique to the reading of literature, is what must be understood in our analyses. As Peter Brooks puts it in his criticism of the ideological excesses of the New Historicism, far from having to assume a fixed philosophic, scientific or monumentalist perpective, "the critic needs a certain humility, a certain awareness that one does not speak ex cathedra but from a very uncomfortable and unstable and indeed slippery ground. [...] One cannot claim to speak for the text until one has attempted to let the text speak through oneself". [ $\underline{34}$ ]

One might retort that literature then condemns critical theory to choosing between Proustain rhapsodies and Platonic silences. But this is once again to fall into the dilemma posed by Socrates: if we cannot speak scientifically about poetry, it is best not to say anything at all. Does the fact that the literary work is not a whole, that its readings are multiple and not univocal, then preclude rational discussion of literature? Bill might well have answered with the solecism that he had made his own, "pas à fait", naturally eliding the tout of which he was justly suspicious.

\section{NOTES}

1. "The Return to Philology", The Resistance to Theory (Minneapolis: University of Minnesota Press, 1986), 26.

2. Peter Brooks, "Aesthetics and Ideology: What Happened to Poetics?" Critical Inquiry 20, n 3 (Spring 1994), 514. 
3. See, for example, Gerald Graff, Professing Literature: An Instituitional History (Chicago: Chicago University Press, 1987).

4. Literary Knowledge: Humanistic Inquiry and the Philosophy of Science (Ithica, Cornell University Press, 1988); I make no attempt to do justice to Livingston's carefully argued and vigorous denunciation of what he calls "framework relativism" within the human sciences; I merely wish to point out that "literature" gets surprisingly short shrift when all is said and done, and that this, whatever the theoretical, logical or methodological cogency of Livingston's critical position, is to ignore the special nature of literary mediation.

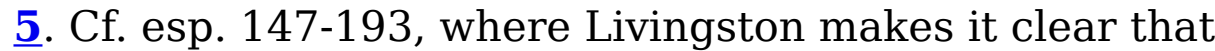
by "unity" he has no intention of advancing the Laplacean dream of a single all-knowing science, but the more restricted claim of a basic methodological agreement common to the sciences.

6. Ibid., 200.

7. Ibid., 198.

8. See Louis Méridier's introduction to his French translation of the Ion, in Platon, [OElig ]uvres complètes (Paris: Les Belles Lettres, 1931), vol. v, 7-28; I have used this edition for the Greek text as well.

9. The Dialogues of Plato, fourth ed., trans. B. Jowett (Oxford: Clarendon Press, 1953), vol. i, 103-117; standard page references will be incorporated in the text.

10. Which could be one way of viewing the ideological "short-circuit" denounced by Brooks as being behind the current institutional malaise; Brooks, art. cit., 517.

11. I am extrapolating; the full quotation is: "the resistance to theory is a resistance to the use of language about language". "The Resistance to Theory", op. cit., 12 .

12. "Why is Theory Foreign?", Theory Between the Disciplines, ed. Martin Kreiswirth and Mark A. Cheetham (Ann Arbor: University of Michigan Press, 1990), 94-95.

13. Ibid., 91 . 
14. "Technical" (and its derivitives) will henceforth be used in the restricted Socratic sense of "pertaining to a technè".

15. Loc. cit., 100.

16. "The Resistance to Theory", op. cit. , 10.

17. Loc. cit., vol. ii, 163-480.

18. Cf. Jowett's note: "the dramatic interest consists entirely in the contrast between the irony of Socrates and the transparent vanity and childlike enthusiasm of the rhapsode Ion" (op. cit., 99). I am suggesting that the conflict runs much, much deeper.

19. In fact, there is a further irony here, this one clearly programmed by Plato: Socrates uses the words "idioton anthropon", literally "a particular person", in order to permit his habitul dialectical movement from the particular (person) to the general (man), and from the multiple (world) to the singular (Idea); Ion, who has no dialectic, speaks only of "man and woman" [andri ... kai ... gunaki], a basic sexual distinction, which, although it comprises all members of the human race, will not allow for the philosophical transistion to the higher level, anthropon. This allows Socrates to slide from the gender woman to the art of the spinster (540c), once again forcing Ion to admit his ignorance of technical knowledge.

20. "The Resistance to Theory", op. cit., 17.

21. Selected Prose of T.S. Eliot, ed. Frank Kermode (London: Faber \& Faber, 1975), 57; subsequent references to this edition will be made in the text.

22. Causeries du Lundi, le 8 décembre 1855. Review article entitled: "Oeuvres complètes de Saint-Amant, nouvelle édition, augmentée de pièces inédites, et précédée d'une Notice par M. Ch.-L. Livet, 2 vol."

23. Nouveaux Lundis, le 21 juillet 1862. Article entitled: "Chateaubriand jugé par un ami intime en 1821".

24. Sartre being perhaps the last and most famous example: I am thinking especially of his method of "existential psychoanalysis" as he applied it to literary criticism, most convincingly demonstrated by his study of Flaubert, L'Idiot de la famille; Sainte-Beuve's steadfast belief in the order of science (minus his 
aestheticizing genius fetish) is also carried over by Livingston.

25. "The perfect embodiment of the New Criticism remains, in many respects, the personality and the ideology of T.S. Eliot...": de Man, "The Resistance to Theory", op. cit., 6.

26. "Chateaubriand jugé par un ami intime en 1821", loc. cit.

27. It is thus no mere hyperbole when Bill Readings calls Eliot "the tutelary deity of [...] humanist literary criticism": art. cit., 88.

28. Cf. especially Eliot, The Idea of a Christian Society (1939), on the maintaining of standards in art and culture: "The increasing organization of advertisement and propaganda - or the influencing of masses of men by any means except through their intelligence - is all against them. The economic system is against them; the chaos of ideals and confusion of thought in our large scale mass education is against them; and against them also is the disappearance of any class of people who recognize public and private responsibility of patronage of the best that is made or written." Loc. cit., 289.

29. "What is a Classic?" (1944), loc. cit., 115-131.

30. For a concise elaboration of this problematic and of the theoretical implications of the classic, see Frank Kermode, The Classic (London: Faber \& Faber, 1975).

31. "Qu'est-ce qu'un classique?" Causeries du Lundi, le 21 octobre 1850.

32. "Journées de lecture" (1906), Pastiches et mélanges, coll. de la Pléiade (Paris: Gallimard, 1971), 174.

33. Ibid., 183.

34. Art. cit., 522 .

Accueil Surfaces | Table des matières | Recherche Surfaces Home Page | Table of Contents | Search

PUM | Livres | Revues | Publications électroniques | Vente et distribution 